\title{
Pemberian Ekstrak Pegagan (Centella Asiatica) Terhadap Uji Organoleptik Daging Ayam Broiler Fase Finisher
}

\author{
Dinul Huda Sihaloho ${ }^{1}$, Aisyah Nurmi ${ }^{2}$, Muharram Fajrin Harahap ${ }^{3}$ \\ ${ }^{1}$ Alumni Fakultas Peternakan Program Studi Peternakan Universitas Muhammadiyah \\ Tapanuli Selatan,e-mail :dinul_huda@yahoo.com \\ ${ }^{2}$ Dosen Program Studi Peternakan Fakultas Peternakan Universitas Muhammadiyah \\ Tapanuli Selatan,e-mail :aisyah.nurmi@um-tapsel.ac.id \\ ${ }^{3}$ Dosen Program Studi AgroteknologiFakultas Pertanian Universitas Muhammadiyah \\ Tapanuli Selatan,e-mail :muharram.fajrin@um-tapsel.ac.id
}

\begin{abstract}
Abstrak
Pegagan (Centellaasiatica) merupakan tanaman liar yang banyak tumbuh di perkebunan, tepi jalan, pematang sawah ataupun adang yang agak basah.Pegagan banyak digunakan sebagai obat alami mengandung berbagai bahan aktif, kandungan bahan aktif itu adalah triterpenoid saponin yang berfungsi untuk meningkatkan aktifitas makrofag yang menyebabkan meningkatnya fagositosis dan sekresi interleukin.

Penelitian ini dilaksanakan di kandang Aneka Ternak MFE (Mix FarminExperience) yang bertujuan untuk mengetahui pengaruh pemberian ekstrak pegagan (Centellaasiatica) dalam air minum terhadap organoleptik (daging) ayam broiler fase finisher.

Metode penelitian yang digunakan dalam penelitian ini adalah Rancangan Acak Lengkap (RAL) yang terdiridari 4 perlakuandan 5 ulangan.Adapun susunan perlakuan yaitu : P0 (Tanpa Pemberian Ekstrak Pegagan), P1 (Pemberian Ekstrak Pegagan sebanyak 100 gr/ 1 liter air), P2 (Pemberian Ekstrak Pegagan sebanyak 200 gr/ 1liter air), P3 (Pemberian Ekstrak Pegagan sebanyak 300 gr/ 1 liter air).

Hasil penelitian pemberian ekstrak pegagan (Centellaasiatica) pada air minum terhadap organ oleptik daging ayam broiler memberikan pengaruh tidak nyata pada mutu hedonik yaitu padadaging $5,360^{\text {th }}$ (putih kekuningan, agak kusam), aroma daging ayam broiler $3,960^{\text {tn }}$ (tida kamis), tekstur daging ayam broiler $3,907^{\text {th }}$ (agaklunak), rasa dagin gayam broiler $4,200^{\text {tn }}$ (gurih), sedangkan pada hedonik memberikan pengaruh tidak nyata yaitu pada warna daging $3,653^{\text {th }}$ (netral), aroma daging ayam broiler 3,560 (netral, tekstur daging ayam broiler $3,560^{\text {tn }}$ Netral, rasa daging ayam broiler $3,507^{\text {tn }}$ (netral).
\end{abstract}

KataKunci : Pegagan, Uji organoleptik, Ayam broiler

\section{PENDAHULUAN}

Ayam broiler (pedaging) adalah ayam ras yang mampu tumbuh cepat sehingga dapat menghasilkan daging dalam waktu relatif singkat (5-7 minggu) yang dipelihara secara intensif.Broiler mempunyai peranan yang sangat penting sebagai sumber protein hewani yang berasal dari ternak. Ditinjau dari segi mutu daging ayam memiliki gizi yang tinggi dibandingkan dengan ternak lainnya,dan jika ditinjau dari segi ekonomis khususnya ayam ras yang populer dengan sebutan ayam broiler ini, merupakan ayam negeri yang bisa dikembangkan secara efisien dan capat dalam pemanenan.

Ayam broiler merupakan ternak yang penting dalam pemenuhan kebutuhan protein hewani masyarakat. Permintaan terhadap daging ayam semakin bertambah seiring dengan meningkatnya penghasilan dan kesadaran penduduk akan pentingnya protein hewani (Ahmad dan Elfawati, 2008). 
Untuk membuat pakan yang baik, bahkan pakan tersebut harus berasal dari bahan lokal yang belum umum digunakan, harganya murah,mudah didapat, nilai gizinya cukup baik serta tidak bersaing dengan kebutuhan manusia.Berbagai macam herbal digunakan oleh peternak dalam ransum ataupun dalam air minum ternak. Berkembangnya penggunaan herbal sebagai obat disebabkan oleh beberapa hal, seperti obat kimia sangat mahal, obat alami mudah didapat dan lumayan murah harganya.

Berbagai herbal dimasukkan kedalam pakan bertujuan untuk mendapatkan produk daging, meningkatkan efisiensi pakan pengganti antibiotik, anti parasit, dan meningkatkan daya tahan tubuh bagi masyarakat Indonesia.Syifaiyah (2008) menjelaskan pemanfaatan tanaman obatobatan bukanlah hal yang baru. Kenyataan menunjukkan bahwa dengan bantuan obatobatan yang berasal dari bahan alami tersebut, masyarakat dapat mengatasi masalah-masalah kesehatan yang dihadapinya.

Salah satu tumbuhan yang dimanfaatkan adalah pegagan.Karena pegagan memiliki khasiat yang banyak sehingga dapat digunakan sebagai obat tradisional (Kristanti, 2010).Pegagan merupakan tanaman obat yang dapat digunakan untuk mengatasi cekaman panas pada ayam (Kusnadi, 2004).Selain itu, penambahan pegagan dipakai sebagai suplemen dan penambah nafsu makan selama pemeliharaan ayam, untuk itu dilakukan penelitian pemberian ekstrak pegagan (Centella asiatica) dalam air minum terhadap uji organoleptik daging ayam dada ayam broiler.

Andria (2012) menuliskan bahwa pegagan (Centela asiatica) juga telah lama dimanfaatkan sebagai obat tradisional baik dalam bentuk bahan segar, kering maupun dalam bentuk ramuan. Tanaman ini telah terbukti memiliki efek farmakologi yang telah terbukti dari beberapa penelitian.Pegagan juga mudah ditemukan di daerah perkebunan, ladang, tepi jalan, pematang sawah ataupun di ladang yang agak basah (Besung, 2009).

\section{METODE PENELITIAN}

\section{Bahan Penelitian}

Penelitian telah dilaksanakan di kandang aneka ternak Mix Farming Experience (MFE) Fakultas Peternakan Universitas Tapanuli selatan selama dua bulan mulai dari bulan Februari sampai Maret Tahun 2017

Ternak yang digunakan adalah ayam broiler berumur 1 hari DOC sebanyak 100 ekor tanpa membedakan jenis kelamin (unsexing), sampel di ambil dari populasi Ayam broiler yang diperoleh dari "poultry shop" dilakukan pengacakan dan ditempatkan 5 ekor setiap petak dan diberi tanda sesuai perlakuan.

Pembuatan ekstrak pegagan dalam air minum dilakukan dengan memilih pegagan yang segar, kemudian pegagan tersebut dicuci dengan air bersih agar tidak ada bakteri ataupun kotoran yang menempel pada pegagan. Kemudian pegagan dihaluskan dengan cara ditumbuk menjadi butiran kecil kemudian direbus dengan air sebanyak 1 liter selama 15 menit, kemudian disaring dengan saringan tepung dan ekstrak pegagan siap diberikan pada ayam broiler sesuai perlakuan. Pemberian ekstrak pegagan dilakukan pada pagi hari dalam jangka sekali dalam seminggu.

\section{Metode Penelitian}

Penelitian dilakukan dengan cara eksperimen menggunakan Rancangan Acak Lengkap (RAL) dengan jumlah perlakuan $(\mathrm{t})=4$, ulangan $(\mathrm{n})=5$, dengan susunan perlakuan ransum adalah P0 (Pemberian tanpa ekstrak pegagan), P1 (Pemberian ekstrak pegagan sebanyak $100 \mathrm{gr} / \mathrm{satu}$ liter air), P2 (Pemberian ekstrak pegagan sebanyak $200 \mathrm{gr} /$ satu liter air), P3 (Pemberian ekstrak pegagan sebanyak $300 \mathrm{gr} / \mathrm{satu}$ liter air ).

Analisis data dilakukan berdasarkan analisis keragaman. Bila hasilnya berbeda nyata antara perlakuan, maka akan dilakukan uji beda nyata terkecil 
atau beda nyata jujur atau uji Duncan's (Mattjik dan Sumerta Jaya, 2002).

KK $<5 \% \quad$ : Uji lanjut pakai Beda Nyata Terkecil (BNT)

$5<\mathrm{KK}<10 \% \quad$ : Uji lanjut pakai Beda Nyata Jujur (BNJ)

KK $>10 \% \quad$ : Uji lanjut pakai

Duncan's Test.

\section{HASIL DAN PEMBAHASAN}

Uji organoleptik terhadap suatu bahan pangan merupakan indikator yang dapat menunjukkan tingkat penerimaan konsumen terhadap produk tersebut.Mutu dan tingkat kesukaan konsumen dalam organoleptik daging dada ayam broiler yang diberi ekstrak pegagan dalam penelitian ini di ukur berdasarkan warna, aroma, tekstur, rasa.

\section{Uji Mutu Hedonik}

Rataan nilai hasil penilaian panelis terhadap uji organoleptik warna, aroma, tekstur dan tekstur daging dada ayam broiler dilihat pada Tabel dibawah ini.

Tabel hasil penelitian pengaruh pemberian ekstrak pegagan (Centella asiatica) terhadap warna, aroma, tekstur dan rasa daging ayam broiler.

\begin{tabular}{|c|c|c|c|c|}
\hline \multirow{2}{*}{$\begin{array}{c}\text { Perla- } \\
\text { kuan }\end{array}$} & \multicolumn{5}{|c|}{ Parameter Penelitian } \\
\cline { 2 - 5 } & Warna & Aroma & Tekstur & Rasa \\
\hline P0 & $5,173^{\text {tn }}$ & $3,760^{\text {tn }}$ & $3,720^{\text {tn }}$ & $4,200^{\text {tn }}$ \\
\hline P1 & $5,120^{\text {tn }}$ & $3,893^{\text {tn }}$ & $3,707^{\text {tn }}$ & $4,107^{\text {tn }}$ \\
\hline P2 & $5,200^{\text {tn }}$ & $3,960^{\text {tn }}$ & $3,653^{\text {tn }}$ & $3,987^{\text {tn }}$ \\
\hline P3 & $5,360^{\text {tn }}$ & $3,693^{\text {tn }}$ & $3,907^{\text {tn }}$ & $3,987^{\text {tn }}$ \\
\hline
\end{tabular}

\section{Warna}

Warna nilai pengaruh pemberian ekstrak pegagan (Centella asiatica) dalam air minum ayam broiler berkisar antara 4,733 (putih kekuningan, kusam) sampai 5,533 (putih kekuningan agak kusam) dalam rataan warna daging 5,213 (putih kekuningan agak kusam).Tingkat rataan warna daging tertinggi pada perlakuan P3 (dengan penambahan ekstrak pegagan sebanyak 300 gram per satu liter air) dengan rataan warna daging ayam broiler 5,360 (putih kekuningan, agak kusam), sedangkan yang terendah pada perlakuan P1 (dengan penambahan ekstrak pegagan sebanyak 100 gram per satu liter air) dengan rataan warna daging ayam broiler 5,120 (putih kekuningan, agak kusam).

Hasil analisis keragaman menunjukkan bahwa perlakuan memberikan pengaruh tidak nyata $(\mathrm{P}>0,5)$ terhadap warna daging ayam broile. Hal ini disebabkan karena pada pengamatan secara visual tidak terdapat perbedaan antara daging ayam broiler yang diberi ransum ekstrak pegagan (P0), (P1), (P2), (P3) dengan daging ayam yang tidak diberi ransum ekstrak pegagan. Faktor-faktor yang mempengaruhi warna daging antara lain adalah pakan, spesies, bangsa, umur, jenis kelamin, stress, pH dan oksigen. Semua faktor tersebut merupakan penentu utama konsentrasi pigmen mioglobin daging (Soeparno, 1994).

\section{Aroma}

Nilai rataan pengaruh pemberian ekstrak pegagan (Centella asiatica) dalam air minum terhadap organoleptik (aroma) daging ayam broiler berkisar antara 3,200 (sedikit amis) sampai dengan 4,333 (agak amis) dengan rataan 3,827 (sedikit amis). Tingkat rataan nilai aroma daging ayam tertinggi terdapat pada perlakuan P2 (penambahan ekstrak pegagan sebanyak 200 gram per satu liter air) dengan rataan aroma daging ayam broiler 3,960 (sedikit amis), sedangkan nilai rataan aroma daging ayam broiler terendah berada pada perlakuan P3 (penambahan ekstrak pegagan sebanyak 300 gram per satu liter air) dengan rataan aroma daging ayam broiler 3,693 (sedikit amis).

Hasil analisis menunjukkan bahwa perlakuan memberikan pengaruh yang tidak nyata $(\mathrm{P}>0,5)$ terhadap aroma daging ayam broiler. Hal ini mungkin disebabkan kadar perlemakan yang tinggi pada daging ayam broiler.Aroma berkembang pada saat daging dimasak, yang merupakan interaksi antara karbohidrat dan asam amino, lemak dan oksidasi termal dan degradasi tiamin (Soeparno, 1994; Northcutt, 2009).

\section{Tekstur}


Nilai rataan pengaruh pemberian ekstrak pegagan (Centella asiatica) dalam air minum terhadap organoleptik (tekstur) daging ayam broiler berkisar antara 3,400 (kurang empuk) sampai 4,133 (agak empuk) dengan rataan 3,747 (kurang empuk). Tingkat rataan tekstur daging ayam broiler tertinggi terdapat pada perlakuan P3 ( dengan penambahan ekstrak pegagan sebanyak 300 gram per satu liter air) dengan rataan nilai 3,907 (kurang empuk), sedangkan nilai rataan tekstur daging ayam broiler terendah terdapat pada perlakuan P2 ( dengan penambahan ekstrak pegagan sebanyak 200 gram per satu liter air) dengan nilai rataan tekstur daging ayam broiler 3,653 (kurang empuk).

Hasil analisis ini menunjukkan bahwa perlakuan memberikan pengeruh tidak nyata $(\mathrm{P}>0,05)$ terhadap tekstur daging ayam broiler. Hal ini mungkin disebabkan cara pemeliharaan yang kurang intensif dan penanganan waktu pemotongan serta pasca pemotongan.

Hal ini juga dapat dipengaruhi oleh jumlah jaringan ikat pada daging.Jumlah jaringan ikat yang lebih banyak mengakibatkan daging lebih keras dibandingkan jaringan ikat yang sedikit (Soeparno, 1991).

\section{Rasa}

Nilai rataan rasa daging ayam broiler berkisar antara 3,733 (kurang gurih) sampai 4,333 (gurih) dengan rataan rasa daging ayam broiler 4,070 (gurih).Tingkat rataan rasa daging ayam broiler tertinggi ada pada perlakuan P0 (pemberian tanpa ekstrak pegagan) dengan rataan rasa daging ayam broiler 4,200 (gurih), sedangkan rataan rasa daging ayam broiler terendah berada pada perlakuan P2 (pemberian ekstrak pegagan sebanyak 200 gram per satu liter air) dengan rataan rasa daging ayam broiler 3,987 (kurang gurih).

Hasil analisis ini menunjukkan bahwa perlakuan memberikan pengaruh yang tidak nyata $(\mathrm{P}>0,05)$ terhadap rasa daging ayam broiler.Hal ini kemungkinan disebabkan kandungan rasa yang dimiliki pegagan tidak terdapat lagi pada ekstrak pegagan yang dicampurkan pada tambahan air minum ayam broiler.Karena salah satu yang mempengaruhi rasa daging ayam broiler adalah pakan yang di konsumsi oleh ternak.

\section{Uji Hedonik}

Rataan nilai hasil penilaian panelis terhadap uji organoleptik warna, aroma, tekstur dan tekstur daging dada ayam broiler dilihat pada Tabel dibawah ini.

Tabel hasil penelitian pengaruh pemberian ekstrak pegagan (Centella asiatica) terhadap warna, aroma, tekstur dan rasa daging ayam broiler.

\begin{tabular}{|c|c|c|c|c|}
\hline \multirow{2}{*}{$\begin{array}{c}\text { Perla- } \\
\text { kuan }\end{array}$} & \multicolumn{4}{|c|}{ Parameter Penelitian } \\
\cline { 2 - 5 } & Warna & Aroma & Tekstur & Rasa \\
\hline P0 & $3,640^{\text {tn }}$ & $3,467^{\text {tn }}$ & $3,560^{\text {tn }}$ & $3,320^{\text {tn }}$ \\
\hline P1 & $3,653^{\text {tn }}$ & $3,520^{\text {tn }}$ & $3,453^{\text {tn }}$ & $3,440^{\text {tn }}$ \\
\hline P2 & $3,613^{\text {tn }}$ & $3,560^{\text {tn }}$ & $3,467^{\text {tn }}$ & $3,507^{\text {tn }}$ \\
\hline P3 & $3,640^{\text {tn }}$ & $3,373^{\text {tn }}$ & $3,493^{\text {tn }}$ & $3,493^{\text {tn }}$ \\
\hline
\end{tabular}

\section{Warna}

Nilai pengaruh pemberian ekstrak pegagan (Centella asiatica) dalam air minum ayam broiler berkisar antara 3,333 ( netral) sampai 3,933 (netral) dengan rataan warna daging 3,687 (netral). Tingkat rataan warna daging tertinggi ada pada perlakuan P1 (dengan penambahan ekstrak pegagan sebanyak 100 gram per satu liter air) dengan rataan warna daging ayam broiler 3,653 (netral), sedangkan yang terendah ada pada perlakuan P2 (dengan penambahan ekstrak pegagan sebanyak 200 gram per satu liter air) dengan rataan warna daging ayam broiler 3,613 (netral). Hasil analisis sidik ragam ini menunjukkan bahwa perlakuan memberikan pengaruh tidak nyata $(\mathrm{P}>0,05)$ terhadap warna daging ayam broiler.Hal ini disebabkan karena pada pengamatan secara visual tidak dapat perbedaan antara daging ayam broiler yang diberi ekstrak pegagan (Centella asiatica) (P0), (P1), (P2), (P3) dengan rataan daging ayam broiler yang tidak diberi ekstrak pegagan.Faktor- faktor yang mempengaruhi warna daging antara lain adalah pakan, spesies, bangsa umur, jenis kelamin, stress, $\mathrm{pH}$ dan oksigen.Semua faktor tersebut merupakan 
penentu utama konsentrasi pigmen mioglobin daging (Soeparno, 1994).

\section{Aroma}

Nilai rataan pengeruh pemberian ekstrak pegagan (Centella asiatica) dalam air minum terhadap organoleptik (aroma) daging ayam broiler berkisar antara 3,200 (netral) sampai dengan 3,867 (netral) dengan rataan 3,480 (netral). Tingkat rataan nilai aroma daging ayam broiler tertinggi terdapat pada perlakuan P1 (penambahan ekstrak pegagan sebanyak 100 gram per satu liter air) dengan rataan aroma daging ayam broiler 3,520 (netral), sedangkan nilai rataaan aroma daging ayam broiler terendah berada pada perlakuan P3 (penambahan ekstrak pegagan sebanyak 300 gram per satu liter air) dengan rataan aroma daging ayam broiler 3,373 (netral).

Hasil analisis pada Tabel 4.14 di atas, $\mathrm{f}_{\text {hitung }}$ lebih kecil dari $\mathrm{f}_{\text {tabel }}$ ini menunjukkan bahwa perlakuan memberikan pengaruh tidak nyata $(\mathrm{P}>0,05)$ terhadap aroma daging ayam broiler. Hal ini kemungkinan disebabkan kadar perlemakan yang tinggi pada daging ayam broiler.Aroma berkembang pada saat daging dimasak, yang merupakan interaksi antara karbohidrat dan asam amino, lemak dan oksidasi termal dan regradasi tiamin (Soeprno, 1994; Northcutt, 2009).

\section{Tekstur}

Nilai rataan pengaruh penambahan ekstrak pegagan (Centella asiatica) dalam air minum terhadap organoleptik (tekstur) daging ayam broiler berkisar antara 3,067 (netral) sampai 3,733 (netral) dengan rataan 3,493 (netral). Tingkat rataan nilai tekstur daging ayam broiler tertinggi terdapat pada perlakuan P0 (pemberian tanpa ekstrak pegagan) dengan nilai rataan 3,560 (netral), sedangkan nilai rataan tekstur daging ayam broiler terendah terdapat pada perlakuan P1 (pemberian ekstrak pegagan sebanyak 100 gram per satu liter air) dengan nilai rataan tekstur daging ayam broiler 3,453 (netral),

Hasil analisis Tabel 4.16 di atas $\mathrm{f}_{\text {hitung }}$ lebih kecil dari $\mathrm{f}_{\text {tabel }}$ ini menunjukkan bahwa perlakuan memberikan pengaruh yang tidak nyata $(\mathrm{P}>0,05)$ terhadap tekstur daging ayam broiler. Hal ini kemungkinan disebabkan cara pemeliharaan yang kurang intensif dan penanganan waktu pemotongan serta pasca pemotongan.

Hal ini juga dapat dipengaruhi oleh jumlah jaringan ikat pada daging.Jumlah jaringan ikat yang lebih banyak mengakibatkan daging lebih keras dibandingkan jaringan ikat yang sedikit (Soeparno,1991).

\section{Rasa}

Nilai rataan rasa daging ayam broiler berkisar antara 3,067 (netral) sampai 3,733 (netral) dengan rataan rasa daging ayam broiler 3,440 (netral).Tingkat rataan rasa daging ayam broiler tertinggi ada pada perlakuan P2 (pemberian ekstrak pegagan sebanyak 200 gram per satu liter air) dengan rataan rasa daging ayam broiler 3,507 (netral), sedangkan rataan rasa daging ayam broiler terendah berada pada perlakuan P0 (pemberian tanpa ekstrak pegagan) dengan rataan rasa daging ayam broiler 3,320 (netral).

Hasil analisis pada Tabel 4.18 di atas, $\mathrm{f}_{\text {hitung }}$ lebih kecil dari $\mathrm{f}_{\text {tabel }}$ ini menunjukkan bahwa perlakuan memberikan pengaruh yang tidak nyata $(\mathrm{P}>0,05)$ terhadap rasa daging ayam broiler. Hal ini kemungkinan disebabkan kandungan rasa yang dimiliki pegagan tidak terdapat lagi pada ekstrak pegaganyang dicampurkan pada air minum. Karena salah satu faktor yang mempengaruhi rasa daging ayam broiler adalah pakan yang dikonsumsi ternak.

\section{KESIMPULAN}

Berdasarkan hasil penelitian dapat disimpulkan bahwa untuk uji organoleptik secara mutu hedonik terhadap daging dada ayam broiler yang diberi perlakuan dengan pemberian ekstrak pegagan memberikan pengaruh yang tidak nyata terhadap uji mutu hedoik warna dan untuk hedonik juga member pengaruh yang tidak nyata terhadap warna, aroma, tekstur dan rasa daging dada ayam broiler. Hasil penlaian simpulkan daging dada ayam broiler untuk warna daging putih kekuningangan agak kusam (netral), aroma agak amis (netral), 
tekstur agak empuk ( netral), dan rasa gurih (netral). Karakteristik tidak berbeda dibandingkan tanpa pemberian ekstrak pegagan.Secara umum bagian dada ayam broiler disukai panelis dan keadaan ini bahwa ekstrak pegagan dapat dimanfaatkan sebagai alternatif campuran air minum ayam broiler.

DAFTAR PUSTAKA

Ahmad dan Elfawati., 2008. Performans Ayam Broiler Yang Diberi Sari buah Mengkudu (Morinda citrifolia).Jurnal Peternakan, Vol.5 (1) Februari 2008 (10-13). Fakultas Pertanian Dan Peternakan Universitas Islam Negeri Sultan Syarif Kasim.Pekanbaru-Riau.

Andria, Y. 2012. Pengaruh Pemberian Ekstrak Daun Pegagan (Centella asiatica (L) Urban) terhadap Kadar Hormon Estradiol dan Kadar Hormon Progesteron Tikus Putih (Rattus noervegicus) Betina.Tesis. Program Studi Ilmu Biomedik Program Pascasarjana Universitas Andalas. Padang.

Besung,

IN.K.2009.PengaruhPemberianEks trakKunyitPadaAnakBabiYang MenderitaColibacillosis.Terdapatpa da

http://ejournal.unud.ac.id/.Diakses tanggal 20 Januari 2016. Suheimi, K. 2007. Saudagar Muhammad. http://www.mail-archive.com/ rantaunet@googlegroups.com/msg 06862.html. Selasa, 29 Januari 201622.05

Kristanti,H. 2010. Penyakit Akibat kelebihan \& Kekurangan Vitamin, mineral \& Elektrolit. Citra Pustaka, Yogyakarta.

Kusnadi, E. 2004.Pegaruh Pemberian Pegagan (Centella asiatica) terhadap Respon Ayam Broiler yang Dipelihara pada Suhu Lingkungan yang Berbeda. Jurnal
Peternakan dan Lingkungan 10(02): 10-14.

Soeparno.1994; Northcutt, 2009.Ilmudanteknologidagingcetak ankeempat. GadjahMadaUniversity Press, Yogyakarta.

Soeparno. 1994. Ilmu dan teknologi daging. Gajah Mada University, Yogyakarta.

Minggu. 